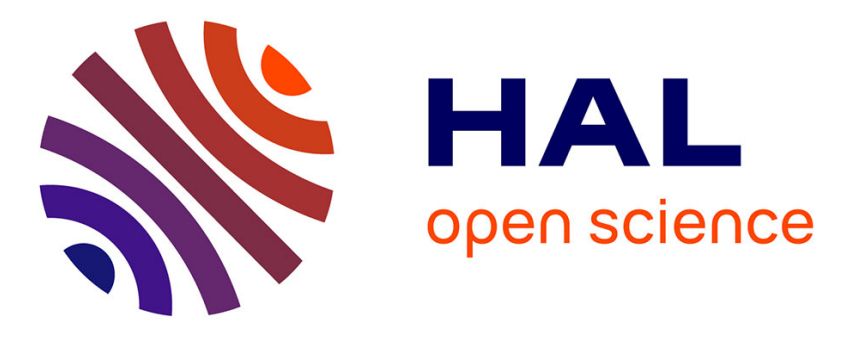

\title{
The Good, The Bad, and The Ugly of a Synchronous Online CS1
}

\author{
Marco Sbaraglia, Michael Lodi, Stefano Pio Zingaro, Simone Martini
}

\section{To cite this version:}

Marco Sbaraglia, Michael Lodi, Stefano Pio Zingaro, Simone Martini. The Good, The Bad, and The Ugly of a Synchronous Online CS1. ITiCSE 2021: 26th ACM Conference on Innovation and Technology in Computer Science Education, Jun 2021, Virtual Event, Germany. ACM, 2, pp.660-660, 26th ACM Conference on Innovation and Technology in Computer Science Education V. 2 (ITiCSE 2021). 10.1145/3456565.3460075 . hal-03338864

\section{HAL Id: hal-03338864 https://hal.inria.fr/hal-03338864}

Submitted on 9 Sep 2021

HAL is a multi-disciplinary open access archive for the deposit and dissemination of scientific research documents, whether they are published or not. The documents may come from teaching and research institutions in France or abroad, or from public or private research centers.
L'archive ouverte pluridisciplinaire HAL, est destinée au dépôt et à la diffusion de documents scientifiques de niveau recherche, publiés ou non, émanant des établissements d'enseignement et de recherche français ou étrangers, des laboratoires publics ou privés. 


\section{The Good, The Bad, and The Ugly of a Synchronous Online CS1}

\author{
Marco Sbaraglia \\ marco.sbaraglia@unibo.it \\ Università di Bologna \\ Bologna, Italy \\ Stefano Pio Zingaro \\ stefanopio.zingaro@unibo.it \\ Università di Bologna \& INRIA \\ Bologna, Italy
}

\author{
Michael Lodi \\ michael.lodi@unibo.it \\ Università di Bologna \& INRIA \\ Bologna, Italy \\ Simone Martini \\ simone.martini@unibo.it \\ Università di Bologna \& INRIA \\ Bologna, Italy
}

\begin{abstract}
This poster illustrates how we redesigned the CS1 course for Math undergraduates to be held online but reflecting the face-to-face (F2F) experience as much as possible. We describe the course structure and the strategies we implemented to maintain the benefits of a synchronous experience. We present the positive and negative aspects that emerged from the students' opinion analysis. We highlight what worked, what did not, and what can be improved to strengthen the perception of a F2F experience and mitigate the "presence paradox" we found: although students are enthusiastic about the online format, most would still prefer a F2F course.
\end{abstract}

\section{KEYWORDS}

emergency remote teaching, distance education, online learning, synchronous learning, CS1, CS1 for Math, non-majors, COVID-19

\section{CONTENT OF THE POSTER}

We present our experience in moving online, on short notice, a traditional F2F CS1 for Math Majors when the COVID-19 pandemic struck Italy in February 2020. Since we value, for cultural and didactic reasons, a synchronous approach to education [1], we adapted the course to maintain that synchronicity as much as possible.

During the semester, we developed interaction protocols to facilitate communication between students and instructors. We selected a set of tools (such as Moodle LMS with automated grading and a Python IDE for beginners) to exploit the digital environment's potential and enhance instructors' online presence. We collected student insights through a mid-term focus group (10 students) and an open-ended questionnaire $(\mathrm{N}=110)$ at the end of the course. We coded each answer with a grounded approach, identifying categories as they emerged, iteratively rediscussing and refining them.

We will present "The Good, the Bad and the Ugly" (referring to Sergio Leone's 1966 movie) of our course online adaptation.

The Good is that students highly appreciated the course. They praised mostly those aspects that favored synchronous interactions (e.g., live-built slides, live programming examples, individual support from TAs during labs, and class chat interactions) and

ITiCSE 2021, June 26-fuly 1, 2021, Virtual Event, Germany

(C) 2021 Copyright held by the owner/author(s).

This is the author's version of the work. It is posted here for your personal use. Not for redistribution. The definitive Version of Record was published in 26th ACM Conference on Innovation and Technology in Computer Science Education V. 2 (ITiCSE 2021), Fune 26-fuly 1, 2021, Virtual Event, Germany, https://doi.org/10.1145/3456565.3460075. leveraged technology to mitigate online learning drawbacks (e.g., TAs presence and support during theory lessons, LMS for sharing materials, homework automatic testing).

The Bad is mainly related to instructors' misconceptions (overreliance on quantitative tools to track live completion of exercises and manage lab time accordingly) and students' misconceptions (overconfidence in instructors' abilities to help in any situation).

The Ugly concerns human aspects of F2F not to be lost, like the possibility for instructors to see students' screens during labs and proactively help them (but with attention to privacy). Moreover, instructors need to be more explicit about didactic choices, which are harder to understand online. Finally, most of our students would choose a F2F course, especially for the unmediated social interactions (didactic and socio-relational) with instructors and peers.

To highlight positive and negative aspects, we look at our analysis in light of the Community of Inquiry (COI) framework [2]. COI describes the essential elements (presences) of successful online higher education: cognitive presence (construction of knowledge through discourse and reflection), teaching presence (design, facilitation, and direction of learning processes), and social presence (learners' ability to feel affectively connected with peers). Students' feedback suggests we preserved the teaching presence. Conversely, the presence paradox ${ }^{1}$ indicates that improvements are still necessary, mainly to help students feel a social presence, too, even online.

Our design, analysis, and discussion can help CS educators and researchers bring a synchronous approach to online teaching. In this year's course, yet mostly online, we systematically analyze the impact of COI presences on students' perception and results while actively fostering the three presences (for example, with group activities to encourage social presence).

\section{REFERENCES}

[1] Matt Bower, Gregor Kennedy, Barney Dalgarno, Mark JW Lee, and Jacqueline Kenney. 2014. Blended synchronous learning: A handbook for educators. Australian Government, Office for Learning and Teaching, Department of Education, Sydney.

[2] D. Randy Garrison, Terry Anderson, and Walter Archer. 1999. Critical Inquiry in a Text-Based Environment: Computer Conferencing in Higher Education. The Internet and Higher Education 2, 2-3 (1999), 87-105.

[3] David A. Joyner, Qiaosi Wang, Suyash Thakare, Shan Jing, Ashok Goel, and Blair MacIntyre. 2020. The Synchronicity Paradox in Online Education. In Proceedings of the Seventh ACM Conference on Learning @ Scale (Virtual Event, USA) (L@S '20). Association for Computing Machinery, New York, NY, USA, 15-24. https: //doi.org/10.1145/3386527.3405922

${ }^{1}$ Paraphrasing the "Synchronicity Paradox" of [3]: students seem to desire synchronicity, despite being attracted to online courses mainly because of asynchronicity. 